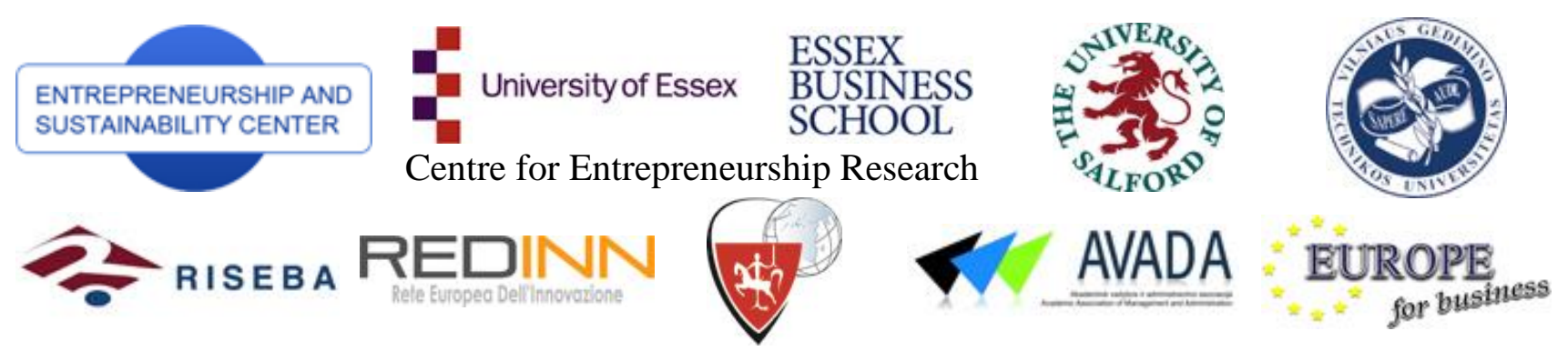

ENTREPRENEURSHIP AND SUSTAINABILITY ISSUES

ISSN 2345-0282 (online) http://jssidoi.org/jesi/aims-and-scope-of-research/

2013 Volume 1(1): 1-9

http://dx.doi.org/10.9770/jesi.2013.1(1)

\title{
ECONOMIC DEVELOPMENT AND ITS INFLUENCE ON STATE CAPITAL STRUCTURE
}

\author{
Agnè Šimelytė', Jūratė Antanavičiené $\dot{2}^{2}$ \\ ${ }^{1,2}$ Vilnius Gediminas Technical University, Faculty of Business Management, \\ Sauletekio ave. 11, LT-10223 Vilnius, Lithuania
}

Emails: ${ }^{1}$ agne.simelyte@vgtu.lt; ${ }^{2}$ jurate.antanaviciene@vgtu.lt

Received 15 January 2013; accepted 20 May 2013

\begin{abstract}
The article deals with the problem of the formation of the state capital and examines the influence of local or foreign capital on the national economy. The extent to which GDP depends on foreign debt, on foreign direct investments and on financial support was determined. GDP, the export/import ratio, inflation and average wage level are attributed to the key factors defining the growth of economy, i. e. depending on the capital structure. The average wage level is employed as the unit for the calculation of labour costs. It can be observed that the nature, intensity, and impact of the foreign capital vary in different business sectors. The conclusion can be drawn that the impact of the foreign capital and its factors depend only on the country-specific features.
\end{abstract}

Keywords: FDI, capital structure, foreign capital, government debt, GDP.

Reference to this paper should be made as follows: Šimelytè, A.; Antanavičienè, J. 2013. Economic development and its influence on state capital structure, Journal of Entrepreneurship and Sustainability Issues 1(1): 1-9.

http://dx.doi.org/10.9770/jesi.2013.1.1(1)

JEL Classifications: F34 F35 H63.

\section{Introduction}

The capital and its classification was examined as early as in the nineteenth century, when the capital was associated with goods and earnings, received for the goods, although there have been other assumptions. Meanwhile, the neoclassical and neo-industrial theories differently interpreted the optimal value of the capital structure for making financial decisions. At that time, various researchers acknowledged that the concept of capital is one of the most controversial and depends on both the classification of assets and the flow of time. In addition, the problems of the examination of the concept of capital arose when the concept of assets began to be used interchangeably with the concept of capital. In the early period, the capital was considered as a whole. Ben-Shabar (1967) noted that unfocused formation of the capital is one of the problems of economic growth. The task of the capital structure is to establish a rational capital structure according to the selected target. In the later period Chase-Dunn (1975), analysed the value and impact of the capital addressing the problem of the capital structure. Other researches such as Cambini, Rondi (2010) emphasize the importance of the capital as a physical property (machinery, vehicles, equipment, and other devices that can be used to improve the production efficiency).

Over time, the concept of foreign capital obtained the heterogeneous comprehension. Currently, the perception of capital is twofold, i. e. it is perceived at the macroeconomic and company level. "From the 
macroeconomic perspective, the capital along with the labour and land constitutes one of the three factors of production. From the company perspective, the capital is defined as the balance capital and the financial capital" (Cibulskienè 2005).

The article deals with the problem of the formation of the state capital and examines the influence of local or foreign capital on the national economy. With reference to the scientific literature, the aim of the article is to identify the main areas of foreign capital, which have the greatest impact on the national economy, to define the main indicators of the economic development of the country which are mostly influenced by the foreign capital, and to determine their relation to GDP. The research methods applied in the paper include the systematic and comparative analysis of the scientific literature as well as the analysis of statistical indicators.

\section{The state capital structure}

The state capital structure is the combination of the national, equity, debt and private capital (Fig.1). The foreign capital is perceived as the investment of funds made by other countries, foreign companies or organizations. The need of the foreign capital and the planned combination depend on the structure and ratio of the national, debt and equity capital. In addition, the national gross domestic product (GDP) and the state debt depend on the structure of the foreign capital in the country as well as on its relation to the public and local private capital.

In the case of different types of foreign funds as well as different nature or duration of the investment, the foreign capital takes the form of multiplicity. However, regardless of the form of the foreign capital, its attraction and distribution still aims at promoting entrepreneurship and the economic growth.

\begin{tabular}{|c|c|c|c|c|c|c|c|}
\hline \multicolumn{8}{|c|}{ Capital distribution according to the forms of ownership in the market } \\
\hline \multicolumn{4}{|c|}{ State capital } & \multicolumn{4}{|c|}{ Private capital } \\
\hline Local state capital & \multicolumn{3}{|c|}{ Foreign state capital } & \multicolumn{2}{|c|}{ Private foreign capital } & \multicolumn{2}{|c|}{ Private local capital } \\
\hline $\begin{array}{l}\text { Tangible non- } \\
\text { financial }\end{array}$ & $\begin{array}{c}\text { Debt } \\
\text { foreign } \\
\text { capital }\end{array}$ & $\begin{array}{c}\text { Investments } \\
\text { from foreign } \\
\text { countries }\end{array}$ & $\begin{array}{l}\text { Foreign } \\
\text { support }\end{array}$ & $\begin{array}{c}\text { Foreign } \\
\text { capital } \\
\text { companies }\end{array}$ & $\begin{array}{c}\text { Foreign } \\
\text { and local } \\
\text { capital } \\
\text { companies }\end{array}$ & $\begin{array}{c}\text { Local large } \\
\text { business }\end{array}$ & $\begin{array}{c}\text { Small and } \\
\text { medium } \\
\text { business }\end{array}$ \\
\hline Local state capital & \multicolumn{5}{|c|}{ Foreign state capital } & \multicolumn{2}{|c|}{ Private local capital } \\
\hline
\end{tabular}

Fig.1. The System of Capital Distribution (according to the forms of ownership in the market). Source: compiled by the authors

The non-borrowed state capital is considered to be "the financial savings of the country, i. e. the portion of the gross national disposable income, which is not spent for consumption or capital formation, is called an external funding opportunity" (Komaromi 2008). When the country experiences more expenditure than income to the budget, its external funding opportunities are negative. This is also known as the need for external financing. The foreign capital reaches the country in various ways. For example: by direct investments, foreign aid or foreign debt, which are difficult to control, especially the latter one, since it mostly covers the gaps in the national budget and is often inexpediently used only to meet the domestic needs rather than to develop business. In addition, the flow of the foreign debt is difficult to control.

In the countries with developing economies, the foreign capital has a different structure than in the countries with mature economies. The former countries attract not only foreign direct investors but also receive financial support from the countries with mature economies. The financial support as a component of the foreign capital is often disproportionately distributed to business regardless of the needs of the region and the industries (Rostow 1953; Conlisk, Huddle 1968; Hymer 1976). The foreign grant funds are used in strict control, however, the problems of distribution of funds caused by the corruption entrenched in the developing countries are not taken into consideration. Meanwhile, the flows and trends of the foreign direct investments are difficult to predict because it is foreign companies themselves that select industries for the development of their business.

\section{The concept of state debt}

The foreign state debt is one of the components of the foreign capital, which typically is associated with long-term commitments. The foreign state debt increases when the income exceeds the expenditure. When the state is not capable to cover the domestic debt, it is obliged to borrow from the domestic and foreign markets. The greatest problem lies in the arrival of the state revenue, in its management and in the control of 
the state debt risk. The main state revenue depends on tax charges. The national budget is formed on the basis of the revenue, however, many countries; especially developing ones, lack sufficient domestic revenue in order to form the non-deficit budget. The state debt is divided into domestic and foreign state debt (the Law of the Republic of Lithuania on the National Debt 2009). The law defines the state debt as follows: "State debt is the aggregate amount of the obligations assumed, but not discharged yet by the general government entities entitled to borrowing in respect of the repayment to creditors of the funds borrowed under government securities distributed by the government of the Republic of Lithuania (hereinafter referred to as LRV), loan agreements, leasing (finance lease) agreements signed and other debt instruments." However, referring to individual legal instruments and classifications, the concept of foreign and domestic debt may vary. In the European Union, the domestic and foreign debt is calculated taking into account the currency of obligations, i. e. if the loan was granted in LTL, it is considered as the domestic debt, and if it was granted in foreign currency - as the foreign debt.

The state often borrows funds in order to cover the deficit of the national budget and the debt liabilities of social security funds as well as to balance the financial flows of the state and to finance state investments. Borrowing grounded on covering of the existing debts and deficits of the budget is also known as "revolver borrowing." The state sector's need to borrow increases the state's national debt, i. e. the amount of outstanding government debt (Mananse, Roubini 2009). This debt includes government securities held by the non-bank private sector, banking sector and foreign sector.

However, the state can borrow only up to a certain limit since at the relevant time the national debt may become unbearable for the state's economy. This is particularly important in order to maintain the stability of the national currency and the international standing of the state. The limit of the state debt is determined by the ratio of GDP and the state debt. The acceptable ratio of GDP and the state debt is 20-60\%. The International Monetary Fund and the World Bank (2001) define the objectives of borrowing management in a similar way: "... to ensure that the financial needs of the government sector are met and the debt liabilities are implemented on time at the lowest possible cost and in accordance with prudent degree of risk."

In the examination of the structure of the state debt, it should be noted that the domestic foreign debt and foreign debt is not the same. The former is formed in the domestic market when the state is incapable to meet its obligations on the domestic market which consist of the aggregate amount of debt of the government, local authorities, the social security and the related objects with the right to borrow.

In turn, the total state debt is divided into direct and indirect. The direct government debt includes liabilities made on behalf of the state; meanwhile the indirect debt consists of liabilities for which the state guarantees were granted (Karazijienè, Sabonienè 2009). The domestic debt is the aggregate amount of the obligations assumed, but not discharged yet by the general government entities entitled to borrowing in respect of the repayment to domestic creditors of the funds borrowed under government securities distributed, loan agreements, leasing (financial lease) agreements signed and other debt instruments.

The examination of the problems of the state debt can be carried out by applying various analytical indicators (Wong, Jomo 2005). The share of the state debt, foreign or domestic debt within the gross domestic product (GDP) shows the size of the state debt and indicates if the funds borrowed by the state can continue to be used as a regulator of the state's economic and social development.

To summarize the opinions of a number of researchers, it can be stated that the state's political and financial stability depends on the state debt. In addition, borrowing is an inevitable and non-reprehensible phenomenon of the economic development; moreover, reasonable borrowing have a positive impact on the economic development of the developing countries. The focused policy and the implementation of economic restructuring measures, strict borrowing restrictions and strong debt limits encourage investors to have more confidence in the country, increase investments, and provide the country with cheaper borrowing abroad (Čiburienè, Povilaitis 2005; Karazijienè, Sabonienè 2008). Certainly, there is always a risk that the state debt will become unbearable for national budgets and aggravate the state's economic development, especially when the borrowed funds are not used for the intended purposes.

\section{The attitude towards the foreign direct investments: the relation between the purposeful selection and the state's well-being}

It is usual that the well-being of the contemporary society depends on the strategic direction of the national and international business. International companies are capable to properly identify and promote local labour force to effectively work in the country (Krupka 2007; Vosylius et al. 2013; Tvaronavičienè et al. 2013). In this way, international companies use the local labour force and compete with local business in the sector. In 
the global market, it is important for competing international companies to adapt to local market and to meet the needs of a local consumer, therefore they establish smaller subsidiary companies. As a result, the subsidiary companies make better use of the latest technologies and management techniques that ensure rapid development in the local economy. However, the market stability can be disrupted if an international company as a market participant introduces new concepts of control (Geroski 1992).

The foreign private capital is also known as foreign investments where private persons or companies, as investors, seek for profits. The foreign investments are divided into foreign securities and the foreign direct investments (hereinafter referred to as FDI), which are classified according to various characteristics (Ginevičius et al. 2005). There is no doubt that the foreign direct investments (FDI) influence the economic development of states, in particular of young countries such as Lithuania. The foreign capital is vital for such a state because it encourages the development of the state in one way or another. Namely FDI indicates the state's openness for investments and the state's integration level into the international market, as well as the growth of the state. In the state economic policy, FDI is often implicitly regarded as a positive phenomenon and is purposefully used to achieve economic growth (Šečkute, Tvaronavičius 2007). However, the scientific literature distinguishes between two types of impact of FDI on the economic growth: positive and negative. A positive attitude is usually based on J. H. Dunning's theory (1977). FDI, "as a factor of economic development, can accelerate the development of the industry because of increasing productivity" (Dunning 1993). Maurer (2011) noted that FDI can contribute to the economic development; however, its impact is rather limited.

In any case, FDI can be viewed as a form of neo-colonialism because of the activities of multinational corporations. However, it is necessary to consider the fact that namely multinational companies determine the level of growth of investments in the country, and especially in those countries which attracted FDI during the process of privatization. In addition, it should be noted that a disproportionate amount of foreign direct investments has been allocated to third-world countries, such as Brazil, Mexico and South Africa, simply for political reasons and in order to avoid taxes. It is also worth mentioning that developed countries are tend to avoid the merging of companies from economically stronger country, for instance, "at the end of late twentieth century, the United States were anxious about the investments of Japanese companies in many branches of the state industry" (Mosley 1986).

Tvaronavičienè and Kalašinskaite (2005) note that, in Lithuania, the individual flows of FDI directed to different industries have a different impact on both the industries receiving FDI and the entire development of the economy. Čegyte and Miečinskienè (2009) highlight the negative impact of uneven distribution of FDI flows in Lithuania and argue that it promotes asynchronous economic development. This raises the question how to attract FDI from foreign capital and to purposefully distribute it. For example, Tvaronavičienė et al. (2008) state that, in Lithuania, during the privatization of AB "Mažeikių nafta" (JSC), the foreign direct investment stimulated by the state did not give the expected results. Such a situation arose because the government followed only the political reasons, regardless of the unique privatization of $\mathrm{AB}$ "Mažeikiu nafta" (JSC), i. e. the successful FDI basically meant the discovery of an investor capable to supply oil. Although the FDI theory of positive impact explains that the profit gained in the domestic market depends on the amount of the foreign capital flows, the cost flexibility, accumulated experience and knowledge drain (Čegytė, Miečinskienė 2009), the aforementioned case of privatization is in contradiction to this theory since the performance result of AB "Mažeikių nafta" (JSC) is almost exclusively dependent on the degree of utilization of productive capacity rather than on the operational effectiveness. The utilization of productive capacity, in turn, depends on the supply of oil (Tvaronavičiene et al. 2008).

Therefore, it can be stated that, in order to attract FDI, or to purposefully use the financial support from other countries, the host country has to acquire the economic skills of country management. In order to achieve this, it is advisable to refer to the practice of the countries with high-economies and to evaluate the future positive or negative effects of the directions of foreign capital expansion. In particular, taking into account the fact that the flows of FDI often depend on the governance structure of the host country (Poukliakova 2008; Tvaronavičienè, Lankauskienè 2011, 2013; Tvaronavičienè, Grybaitė 2012).

In addition, FDI, its attraction and management are affected by the external and internal factors of the country. Transnational companies choose the country for more favourable taxes, for incentives to the creation of business, for open country's economy, which is formed by the government's foreign domestic policy. Foreign investors are deterred by the corruption entrenched in the country and the bureaucratic mechanism, which suspends the establishment of the company and postpones the start of business. The researchers Žemgulienè and Zaleskyte (2006) examined the impact of the investment structure on the national economic growth and determined that FDI has different effects in the industrial and service sector. 
According to them, the increasing FDI flows into the services sector affect the economic growth rates, and increasing investments in the industry accelerate the growth of economy. Based on the findings (Table 1), it can be said that in order to achieve a positive effect of FDI, the state must take into consideration the development trends of the industrial and service sector (Tvaronavičienè, Lankauskienè 2011). It is likely that once a certain level of FDI is reached, after a certain period of time, the effect or direction of investments may vary in different business sectors (Kalašinskaitė 2009).

Table 1. The Most Significant Factors Determining FDI in Developing and Transition Countries

\begin{tabular}{|l|l|}
\hline Factor & Significance \\
\hline $\begin{array}{l}\text { Amounts of previous } \\
\text { FDI }\end{array}$ & indicates a potential FDI factor \\
\hline Growth of GDP & defines the market size \\
\hline $\begin{array}{l}\text { Average rate of } \\
\text { remuneration }\end{array}$ & allows to measure labour costs \\
\hline Export/import ratio & $\begin{array}{l}\text { indicates the country's openness } \\
\text { to other countries }\end{array}$ \\
\hline Inflation & $\begin{array}{l}\text { is considered to be the unit of the } \\
\text { state's risk and the consequence } \\
\text { of the macroeconomic policy }\end{array}$ \\
\hline Local investments & indicates the business climate \\
\hline
\end{tabular}

Source: composed by authors with reference to Ginevičius et al. 2005; Žemgulienė, Zaleskyte 2006; Eremina 2009; Kalašinskaitė 2009; Tvaronavičienè, Tvaronavičius 2006; Tvaronavičienè et. al. 2005

\section{Definitions of the financial support and the determination of its impact on the development of the state}

The foreign financial support is granted in the forms of grants, subsidies and loans on favourable conditions. In the early stage of development of the state, when imports exceed exports, the lack of national financial resources or payment problems may arise. This leads to the need for financial support. Taking into account the country's needs and integration into the global society, the state can receive the targeted financial support from the international organizations and foundations. Such financial support has been granted to the thirdworld and other developing countries since 1960. At that time, it was believed that the financial support can be granted only to the third-world country, i. e. this type of foreign capital has "to move from rich to developing countries" (Conlisk, Hudle 1968; Tvaronavičienè et al. 2013). It was agreed that the financial support creates a positive attitude towards the international community, reduces the political tension between the countries, thus promoting the harmonious development of the developing countries. When assessing the beneficiaries, the alternative criteria allowing to determine the recipient country were identified, such as poverty level, national income. Grants, loans on favourable conditions or services from the developed countries or non-governmental organizations were granted to the developing countries.

During the integration into the EU, favourable conditions for the foreign capital to enter occurred in Lithuania and other transition countries. As a result, in Lithuania, FDI became particularly significant in some business sectors, a special priority focus is given to the EU support funds. The significant benefit of the financial support is closely related to the intensity of support in the specific industry or region. Jakaitiene and Klyvienè (2007) argue that EU support indirectly promotes the attraction of FDI into the country. However, it is observed that the benefit of investment varies in different business sectors (Ginevičius et al. 2008; Tvaronavičienè et al. 2013).

The financial and not only financial support is granted for a wide variety of applications, including grants (goods of frequent consumption in order to facilitate the short-term deficit of goods, for example, during famine in Ethiopia), rehabilitation (eg., restoration of buildings after the war), stabilization (in particular, a short-term grant helping to conduct balanced payments until the state itself is able to do so), and "the longterm support, which aims at raising the level of long-term income" (Mosley 1986). However, the financial support does not guarantee a sustainable development of the state (Tamošiūnienè et al. 2007). It is likely that many financial support programs will be criticized since the support programs may leave defects in the internal economic development and create political dependence of the countries seeking sustainable development, especially if the countries choose inappropriate development methodologies or disproportionately use the funds according to the residential areas. 
Razauskas (2008) points out another negative aspect of financial support for the country, i. e. "the successful use of the support has a negative impact on the inflation control." The negative effect is particularly strong when the donor country gives financial support with certain limitations. The recipient country may be forced to import goods from the donor country, which are usually supplied at higher prices, but of lower quality than in the international markets. In most cases, such donor countries are interested in resolving their own settlement problems, therefore the granted support is not huge (Cass 2007).

\section{The interaction of the foreign direct investments and the state external debt with the country's GDP}

After the start of the economic crisis in Lithuania, the flows of revenue into the national budget reduced. Due to rising unemployment, social benefits significantly increased. This resulted in a more rapid gross expenditure of the government sector. According to the Bank of Lithuania (2009) the government debt comprised 15,6 percent of GDP in 2008. However, compared to the year 2007, the ratio between the debt and GDP fell by 1,4 percent (Fig. 2). The domestic debt comprised 35,8 percent of gross debt. It grew by 13,6 percent within a year and resulted in the increase of the gross debt as the foreign debt slightly decreased within a year.

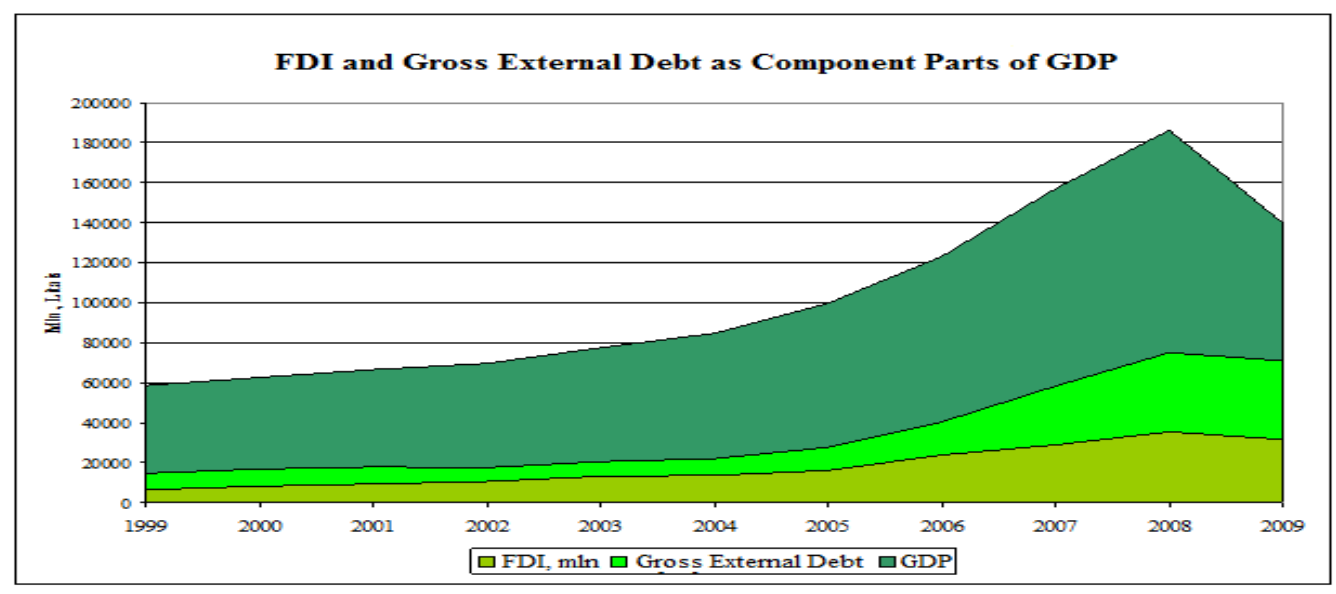

Fig.2. Gross External Debt and FDI as Component Parts of GDP. Source: Statistics Lithuania

However, in 2009, the continuing growth of unemployment, the decrease of remuneration and the diminished consumption determined event lower revenue flows into the budget. In this way, the state, lacking their own financial resources, was forced to borrow from the foreign markets. The government foreign debt contained the Eurobonds and the securities of the Lithuanian Government. In comparison with 2008, when the government did not issue any Eurobond, the state external debt had a tendency to decline (Table 2).

FDI, which has a large impact on the Lithuanian financial system and economic activity, also decreased because of the economic crisis. Within a decade, the foreign capital flows were rapidly growing with the expected future return. FDI flows intensified after Lithuania entered the European Union. The main channels through which the investments reached the region were as follows: FDI (including the establishment and acquisition of credit institutions), portfolio investments (including investments in stocks and bonds).

Table 2. Government Sector External Debt

\begin{tabular}{|l|l|l|l|l|l|}
\hline & $\mathbf{2 0 0 4}$ & $\mathbf{2 0 0 5}$ & $\mathbf{2 0 0 6}$ & $\mathbf{2 0 0 7}$ & $\mathbf{2 0 0 8}$ \\
\hline Total & 7495,9 & 8010,9 & 10218,7 & 11226,6 & 11161,3 \\
\hline $\begin{array}{l}\text { The central } \\
\text { government }\end{array}$ & 7466,7 & 7983,7 & 10195,3 & 11199,8 & 11125,8 \\
\hline $\begin{array}{l}\text { The local } \\
\text { government }\end{array}$ & 29,2 & 27,2 & 23,4 & 26,8 & 35,5 \\
\hline
\end{tabular}

Source: Statistics Lithuania 2013 


\section{Conclusions}

To sum up the perception of the state capital and its influence on the development of the country, it should be noted that a controversial impact of the state capital structure on the economic development is observed. It should be noted that the task of the capital structure is to establish a rational capital structure according to the selected target. In case of the foreign capital and the state capital, a part of which is borrowed, the problem arises how to purposefully distribute it. This problem can be solved when the state has adequate management skills.

The impact of foreign capital and its factors depend only on the features of the host country such as market size, political - economic stability and the level of human resources in the country.

The granted financial support creates a positive attitude towards the international community, reduces the political tension between the countries, thus promoting the harmonious development of developing countries. In addition, it increases the capabilities of the state to increase the flows of FDI.

The state foreign debt consists of government securities held by non-bank private sector, banking sector and foreign sector. While these securities are actively bought and held, the national debt may grow. However, the state can borrow only up to a certain limit since the national debt may become unbearable to the state's economy at a certain point in time.

\section{References}

Ben-Shabar, H. 1967. Capital formation and government capital policy in developing economies, Journal of Development Studies 4(1): 86-96.

Cambini, C.; Rondi, L. 2010. Incentive regulation and investment: evidence from European energy utilities, Journal of Regulatory Economics 38: 1-26. doi:10.1007/s11149-009-911-6.

Chase-Dunn, C. 1975. The effects of international economic dependence and inequality: a cross-national study, American Sociological Review 40:720-738.

Cass, F. 2007. Attracting FDI to transition countries: the use of incentives and promotion agencies, Transnational Corporations 16(2): 77-118.

Cibulskienė, D. 2005. Imoniu kapitalo struktūros modeliavimas finansu rinkos globalizacijos salygomis: Disertacija [Modelling enterprise capital structure under the effects of globalization in the financial market: Dissertation]. Vilniaus Gediminas Technical University. Vilnius: Technika. 175 p.

Conlisk, J.; Huddle, D. 1968. Allocating Foreign Aid: An Appraisal of a Self Help Model, The Journal of Development Studies (September): 245-251.

Čegytė, O.; Miečinskienė, A. 2009. Tiesioginių užsienio investicijų poveikio tyrimas [Analysis of effects of direct foreign investment], Mokslas - Lietuvos ateitis [Science - the future of Lithuania] 1(3): 9-12.

Čiburienè, J.; Povilaitis, M. 2005. Valstybės skolos poveikis ekonomikai [The effects of national debt on the economy], Organizaciju vadyba ir sisteminiai tyrimai [Organization management and systemic analyses] 33: 23-36.

Dunning, J. H. 1993. Multinational enterprises and the global economy. Addison-Wesley, Harlow.

Dunning, J. H. 1977. Trade, Location of Economic Activity and MNE: A Search for an Eclectic Approach, in Ohlin, B.; Hesselborn, P.; Wijkman, P.M. (Eds.). The international allocation of economic activity: proceedings of a Nobel Symposium held at Stockholm, 395-418. London: The Macmillan Press Ltd.

Eremina, S. F. 2009. The Impact of Foreign Capital on the Country Economy, Management Science and Engineering 3(3): 69-90.

Geroski, P. A. 1992. Vertical Relations between Firms and Industrial Policy, Economic Journal 102 (401): $138-147$.

Ginevičius, R.; Podvezko, V; Bruzgè, Š. 2008. Evaluating the Effect of State Aid to Business by Multicriteria Methods, Journal of Business Economics and Management 9(3): 167-180.

Ginevičius, R.; Rakauskienė, O. R.; Patalavičius, R.; Tvaronavičienė, M.; Kalašinskaitė, K.; Lisauskaite, V. 2005. Eksporto ir investiciju plettra Lietuvoje: Monografija [Expansion of export and investments in Lithuania: Monograph]. Vilnius: Technika. 363 p.

Hymer, S. H. 1976. The International Operations of National Firms: A Study of Direct Foreign Investment. Cambridge, MIT Press. 
Jakaitienè, A.; Klyvienè, V. 2007. Europos Sajungos finansinès paramos poveikis Lietuvos ekonominei raidai [The effects of EU financial support on the development of the Lithuanian economy, Pinigu studijos: Ekonomika ir praktika [Money studies: Economics and practice] 2: 24-46.

Kalašinskaite, K. 2009. The Impact of Foreign Direct Investments on Economic Development: Case of Lithuania and other Baltic States: summary of dissertation. Vilnius Gediminas Technical University. Vilnius: Technika. 24 p.

Karazijienė, Ž.; Sabonienė, A. 2008. Valstybès skolinimosi poreikio prognozavimas [Forecasting the need for further national debt], Ekonomika ir vadyba [Economics and Management] 13: 538-545.

Karazijienè, Ž.; Sabonienė, A. 2009. Valstybès skolos struktūra ir valstybès skolinimosi įtaka Lietuvos ekonomikai [Structure and effects of national debt on the Lithuanian economy], Ekonomika ir vadyba [Economics and Management] 14: 271-279.

Komaromi, A. 2008. The structure of external financing: Is there a reason to worry about financing through dept? MNB bulletin, April: 14-23.

Krupka, S. 2007. The effects of the capital market on the transformation of the Ukrainian economy, Technological and Economic Development of Economy 13(3): 198-203.

Mananse, P; Roubini, N. 2009. Rules of Thumb for Sovereign Debt Crises, Journal of International Economics 78: 192-205.

Maurer, J. 2011. Relationship between Foreign Subsidiaries: Competition Corporation in Multinational Plant engineering Companies. Gabler, Germany.

Mosley, P. 1986. Overseas Aid: Its Defense and Reform. Hemel Hempstead.

Razauskas, T. 2008. Europos Sajungos ekonomika: aktualios problemos ir raidos perspektyvos [EU economics: current problems and prospects for development], Viešasis administravimas [Public administration] 3(19): 6-21.

Rostow, W. W. 1953. The stages of economic growth. 2nd edition. Cambridge England: Cambridge university press.

Poukliakova, S. 2008. Bayesian estimates of FDI flows: the governance problem, Applied Economics Letters 15: 593-596.

Statistics Lithuania. 2013. Available on the Internet: < http://www.stat.gov.lt/lt>.

Šečkutė, L.; Tvaronavičius, V. 2007. Analysis of foreign direct investment in the Baltic States, Verslas: teorija ir praktika [Business: Theory and Practice] 8(3): 153-160.

Tamošiūnienè, R.; Šidlauskas, S; Trumpaite, I. 2007. EU structural support and its impact on Lithuania's progress, Journal of Business Economics and Management 8(3): 177- 187.

The Bank of Lithuania. 2009. Lithuanian Economy Review, December. Available on the Internet: 〈http://www.lb.lt>.

The International Monetary Fund, the World Bank. 2001. Guidelines for Public Debt Management. Available on the Internet: $<\mathrm{http}: / /$ www.imf.org/external/np/mae/pdebt/2000/eng/

guide.pdf $>$.

Tvaronavičienė, M.; Grybaitè, V. 2012. Sustainable development and performance of institutions: approaches towards measurement, Journal of Security and Sustainability Issues 1(3): 167-175.

Tvaronavičienè, M.; Grybaitè, V.; Tunčikienè, Ž. 2013. Globalization drivers in developed and less developed countries: if consistent patterns can be traced, Journal of Security and Sustainability Issues 2(4): 5-11. doi: 10.9770/jssi.2013.2.4(1)

Tvaronavičienė, M.; Kalašinskaitè, K. 2005. Preconditions of effective privatization [Kai kurios efektyvaus privatizavimo prielaidos], Verslas: teorija ir praktika [Business: Theory and Practice] 6(1): 62-66.

Tvaronavičienė, M; Kalašinskaitè, K.; Peleckis, K. 2008. Case Study of Lithuanian Strategic Company's "Mazeikiu nafta" Privatization, Verslas: teorija ir praktika [Business: Theory and Practice] 9(2): 98-104. doi: 10.3846/1648-0627.2008.9.97-104.

Tvaronavičienè, M.; Lankauskienè, T. 2011. Plausible foreign direct investment' impact on sustainable development Indicators of differently developed countries, Journal of Security and Sustainability Issues 2011 1(1): 25-36. doi: 10.9770/jssi.2011.1.1(3)

Tvaronavičienė M.; Lankauskienè, T. 2013. The impact of production factors and economic structures on economic development, Verslas: teorija ir praktika 14(1): 5-16. doi: 10.3846/btp.2013.01

Tvaronavičienė, M.; Tvaronavičius, V. 2006. Kai kurie Lietuvos ekonominio augimo aspektai [Some aspects of Lithuanian Economic Growth], Verslas: teorija ir praktika [Business: Theory and Practice] 7(4): 232-236. 
Law on the National Debt. 2009. Seimas of the Republic of Lithuania. Available on the Internet: <http://www.lrs.lt>.

Žemgulienè, J.; Zaleskytė, J. 2006. Foreign direct investments in Lithuania - sectors of investment as determinant of growth, Organizaciju vadyba ir sisteminiai tyrimai [Management of Organizations: Systematic Research] 38: 195-203.

Vosylius, E.; Rakutis, V.; Tvaronavičienè, M. 2013. Economic growth, sustainable development and energy security interrelation, Journal of Security and Sustainability Issues 2(3): 5-14. doi: 10.9770/jssi.2013.2.3(1)

Wong, Hwa Kiong; Jomo, K. S. 2005. Before the Storm: The Impact of Foreign Capital Inflows on the Malaysian Economy, $1966-$ 1996, Journal of the Asia Pacific Economy 10(1): 56-69. 